\title{
PENGARUH KONTEN DAN GAYA KOMUNIKASI DI PLATFORM KONSULTASI BERBASIS ONLINE@IBUNDA_ID TERHADAP BRAND AWARENESS
}

\author{
Deska Dera Aisah, Yuliana Riana Prasetyawati \\ Sekolah Tinggi Ilmu Komunikasi LSPR \\ deskadera@gmail.com,yuliana.rp@1spr.edu
}

Diajukan: 29-03-2018; Direview: 29-05-2018; Diterima: 24-06-2018;

\begin{abstract}
This research was conducted with the aim to know the influence of content and communication style in social media to brand awareness Ibunda.id. The development of technology and internet trigger various companies using social media in conveying information and increase brand awareness through social media. The theory used in this research is Social Information Processing as main theory and concepts of information and style of communication. The research method used in this research is quantitative method. Data collection was done by using questionnaires distributed to 100 respondents of Ibunda's service userswho follow Instagram @ibunda_id account. Based on the research, the disseminated content and communication styles used by Ibunda influence simultaneously at brand awareness.
\end{abstract}

Keywords : Content, Style of Communication, Social Media, Brand Awareness

\begin{abstract}
Abstrak
Ibunda.id adalah sebuah platform konsultasi berbasis digital yang diharapkan bisa menjadi teman curahan hati (curhat) bagi masyarakat. Ibunda akan memberikan solusi dari permasalahan-permasalahan sehari-hari seperti masalah percintaan, keluarga, pertemanan bahkan masalah diri. Namun, kesadaran khalayak terhadap keberadaan Ibunda.id sebagai wadah curhat yang dapat memberikan solusi yang efektif untuk menyelesaikan sebuah masalah masih relatif rendah. Oleh karena itu, penelitian ini dilakukan dengan tujuan untuk mengetahui pengaruh konten dan gaya komunikasi dalam social media terhadap brand awareness Ibunda.id. Perkembangan teknologi dan internet memicu berbagai perusahaan menggunakan social media dalam menyampaikan informasi dan meningkatkan brand awareness melalui social media. Teori yang digunakan dalam penelitian ini adalah Social Information Processing. Metodologi penelitian yang digunakan adalah kuantitatif. Pengumpulan data dilakukan dengan menggunakan kuesioner yang disebarkan kepada 100 responden pengguna layanan Ibunda yang mengikuti akun Instagram @Ibunda_id. Temuan penelitian menyatakan terdapat pengaruh yang positif dan signifikan antara konten dan gaya komunikasi terhadap brand awareness. Gaya komunikasi merupakan faktor yang dominan dalam meningkatkan brand awareness Ibunda.id.
\end{abstract}

Kata kunci : Konten, Gaya Komunikasi, Social Media, Brand Awareness

\section{PENDAHULUAN}

$\mathrm{M}$ edia sosial telah menjadi bagian bagi kehidupan sehari-hari masyarakat kota besar seperti Jakarta. Menurut Kaplan dan Haenlein (2010:68-69), media sosial adalah sekelompok aplikasi berbasiskan internet yang dibangun berdasarkan kerangka pikiran ideologi dan teknologi dari Web 2.0, dan memungkinkan terbentuknya kreasi dan pertukaran isi informasi dari pengguna internet. Media sosial menjadi wadah bagi para penggunanya untuk bertukar informasi, pembentukan citra diri, dan sebagai media promosi suatu produk atau perusahaan.

Menurut penelitian yang dilakukan oleh We Are Social pada tahun 2017, pengguna aktif internet di Indonesia berjumlah 132,7 juta di mana 92 juta terdiri dari pengguna aktif media social yang sebanyak 106 juta penggunanya mengakses media 
sosial melalui perangkat mobile dari jumlah total 371,4 juta pengguna smartphone. Jumlah tersebut terbilang mengalami pertumbuhan yang signifikan dibandingkan periode yang sama di tahun 2016 yakni hanya sekitar 88,1 juta pengguna Internet pada awal tahun 2016. Pertumbuhan jumlah pengguna internet ini turut diiringi oleh meningkatnya jumlah pengguna layanan media sosial. Hanya berjumlah 79 juta pada tahun lalu, angka tersebut kini telah naik menjadi 106 juta pengguna. Para pengguna yang secara aktif menggunakan media sosial di perangkat mobile pun naik dari angka 66 juta menjadi 92 juta.

Social media sendiri merupakan kombinasi dari perkembangan teknologi dan komunikasi yang masuk kedalam kategori new media. New media merupakan produk dari komunikasi yang termediasi teknologi yang terdapat bersama dengan computer digital (Creeber dan Martin, 2009:72). Banyaknya fitur dan fungsi social media menjadikan social media sebagai wadah atau medium bagi masyarakat khususnya para pengguna gadget dalam memberikan dan memperoleh informasi, media dalam mengekspresikan diri, maupun sebagai media promosi, yang dilakukan baik sebagai pengguna individu maupun organisasi dan perusahaan.

Media Sosial memiliki berbagai fungsi, dan salah satunya dimanfaatkan oleh organisasi dan perusahaan untuk melakukan kegiatan promosi. Media sosial dinilai telah mampu mengurangi beban biaya promosi yang sangat besar untuk mengenalkan dan memasarkan produk layanan yang ditawarkan. Dengan berkembangnya bisnis melalui media online dan didukung oleh penetrasi internet yang sangat cepat banyak perusahaan baru dengan platform website (berbasis situs) bermunculan. Perusahaan tersebut disebut startup. Menurut Arjanti dan Mosal (2012:36), start up merupakan perusahaan berbasis teknologi informasi yang menyediakan jasa atau produk mereka melalui offline atau online, dan dengan berkembangnya keadaan jaman sekarang startup lebih dikenal dengan perusahaan kecil yang memiliki hosting dan domain berupa website atau blog.

Bagi perusahaan start-up, hal utama yang harus dibangun dari masyarakat adalah kesadaran merek atau brand awareness. Brand awareness memiliki pengertian yaitu kesanggupan seseorang calon pembeli untuk mengenali, mengingat kembali suatu merek sebagai bagian dari suatu kategori produk tertentu (Durianto, Sugiarto dan Sijintak, 2004:4).

Ibunda adalah sebuah platform konsultasi berbasis digital yang diharapkan bisa menjadi teman curahan hati (curhat) bagi masyarakat. Ibunda akan memberikan solusi dari permasalahanpermasalahan sehari-hari seperti masalah percintaan, keluarga, pertemanan bahkan masalah diri. Selain itu, Ibunda juga aktif memberikan artikel-artikel yang berkaitan dengan masalah sehari-hari. Ibunda sendiri berada dibawah perusahaan start-up bernama Amplified yang berdiri ada tahun 2015 .

Platform konsultasi online sudah muncul sejak tahun 2015, salah satunya adalah Riliv yang menyediakan layanan curhat dengan para pakar psikolog yang disebut Rellever. Untuk menggunakan jasa ini, para penggunanya diharuskan memilih paket konsultasi dan melakukan pembayaran terlebih dahulu dengan kisaran harga paket dari Rp 79,000 untuk 2x sesi curhat sampe Rp 799,000 untuk paket. Kemudian, belum lama ini pada April 2017, PsyLine hadir sebagai salah satu platform konsultasi online untuk berbagi cerita. Dalam PsyLine, penggunanya dapat melakukan konseling dan konsultasi dengan psikolog profesional secara online atau bertemu langsung untuk mendapatkan layanan psikologis. Perbedaan Riliv dengan Ibunda adalah Riliv mematok harga konsultasi bagi para penggunanya, sedangkan Ibunda dan PsyLine memberikan layanan konsultasi gratis. Lalu, PsyLine terbilang beru dibanding Ibunda uang sudah lebih dulu hadir yaitu pada tahun 2016 .

Secara aktif, Ibunda melakukan update informasi dan konten melalui sosial media seperti menggunggah artikel, quotes, video pendek, konten interaktif dengan menggunakan animasi maupun foto seperti dalam social media Instagram @ibunda_id. Secara aktif, Ibunda melakukan update informasi dan konten melalui social media mereka seperti menggunggah artikel, quotes, video 
pendek, konten interaktif dengan menggunakan animasi maupun foto seperti dalam social media Instagram@ibunda_id. Penggunaan media sosial Instagram ditujukan untuk menarik perhatian khalayak untuk menggunakan layanan konsultasi Ibunda dalam menyelesaikan masalah-masalah yang sedang dialami.

Gaya komunikasi merupakan cara penyampaian dan gaya bahasa yang baik (Widjaja. 2000:7). Gaya komunikasi yang digunakan oleh Ibunda di akun media sosialnya bersifat non-formal dan sederhana karena segmentasi Ibunda adalah anak muda yang berusia 18-25 tahun.

Adapun selain gaya komunikasi, aspek lain yang perlu diperhatikan untuk menarik perhatian khalayak adalah konten. Konten-konten yang diberikan dan diunggah dalam akun media sosial Instagram Ibunda terbilang beragam. Konten terdiri dari judul kemudian digabungkan dengan informasi singkat, yang dipadukan dengan foto maupun video dan design yang sesuai dengan warna dari logo Ibunda. Ibunda kerap membahas mengenai permasalahan yang lekat dengan kehidupan sehari-hari.

Gaya berkomunikasi terkadang menjadi lebih penting dari konten komunikasi tersebut. Bagaimana tidak, banyak orang yang memahami konten dengan baik tetapi pesan komunikasinya tidak sampai atau tidak diterima orang lain karena ketidakmampuan dalam menyampaikan pesan tersebut. Namun, yang masih menjadi masalah adalah masih rendahnya tingkat kepercayaan khalayak untuk menjadikan Ibunda sebagai wadah curhat yang dapat memberikan solusi yang efektif untuk menyelesaikan sebuah masalah. Maka, apakah ada pengaruh antara konten dan gaya komunikasi di platform konsultasi berbasis online secara simultan terhadap brand awareness?

\section{LITERATUR DAN METODOLOGI}

Social Information Processing menjelaskan bagaimana komunikator bertemu melalui komunikasi berbasis teks komputer, mengembangkan kesan dan hubungan interpersonal. Pada mulanya, Social Information Processing mengasumsikan bahwa komunikator akan termotivasi untuk membangun hubungan online sebagai kebutuhan pribadi.

Namun, pada perkembangannya kini, dapat diidentifikasi faktor-faktor yang meningkatkan dorongan motivasi untuk membangun hubungan online, yaitu: (1) antisipasi interkasi berikutnya di masa depan, dan (2) skeptisisme. Interaksi masa depan diduga mengacu pada prospek bahwa komunikator yang bertemu secara online akan terus memiliki kontak ke masa depan. Komunikator yang mengharapkan kontak dengan mitra mereka di masa depan lebih mungkin untuk bertukar pesan lebih banyak dan membangun hubungan, daripada yang tidak mengharapkan kontak di masa depan. Sedangkan skeptisisme mengacu pada sikap komunikator terhadap penggunaan computer mediated communication untuk membangun persahabatan. Komunikator yang kurang skeptis membentuk lebih banyak persahabatan online, dibandingkan dengan yang memiliki level skeptisime yang tinggi (Littlejohn dan Foss, 2009: 897-899). Sementara, Bentuk transaksi komunikasi bermediasi komputer terjadi pada saat pengelola Instagram Ibunda menyampaikan informasi dengan menggunggah konten-konten. Pertukaran informasi terjadi melalui perangkat keras, yaitu penggunaan telepon pintar antara pengelola Instagram Ibunda dengan telepon pintar dan pengikut Instagram @ibunda_id.

Dalam penelitian ini, peneliti akan meneliti hubungan yang berusaha dibangun oleh platform konsultasi online Ibunda melalui media sosial Instagram@ibunda_id dengan para followers dan pengaruh gaya komunikasi dan konten di media sosial Instagram @ibunda_id terhadap brand awareness.

Informasi menurut Shannon dan Weaver yang dikutip oleh Severin dan Tankard, (2005: 16), adalah "information is attern matter energy that affects the probabilities of aternatives available to an individual makin decision." Informasi adalah energi yang dipolakan, yang mempengaruhi individu dalam mengambil keputusan dari kemungkinan pilihan-pilihan yang ada." (Wiryanto, 2004: 16)

Kemudian, Wiryanto mengemukakan definisi informasi adalah hasil dari proses intelektual seseorang. Proses intelektual adalah mengolah 
atau memroses stimulus, yang masuk ke dalam diri individu melalui pancaindera, kemudia diteruskan ke otak atau pusat syaraf untuk diolah atau diproses dengan pengetahuan, pengalaman, selera, dan iman yang dimiliki seseorang. Setelah diproses, stimulus itu dapat dimengerti sebagai informasi. Informasi ini bisa diingat oleh otak bila dikomunikasikan kepada individu atau khalayak, makan akan berubah menjadi pesan (Wiryanto,2004: 29).

Kualitas informasi dapat ditentukan melalui beberapa aspek. Menurut John Burch, informasi yang berkualitas ditentukan melalui 3 hal, yaitu (Wiryanto, 2004:30): 1) Accuracy (kecermatan) yaitu informasi yang diberikan harus akurat dan terbebas dari kesalahan-kesalahan. Infomasi harus akurat karena penyampaian informasi ke penerima memungkinkan banyak terjadinya gangguan (noise) yang dapat merubah informasi tersebut. 2) Timeliness (tepat waktu) yakni informasi dihasilkan pada saat diperlukan sehingga dapat dikatakan sebagai informasi yang tepat waktu, 3) Relevancy (relevansi), adanya relevansi dalam sebuah informasi yang berhubungan dengan kepentingan pengambilan keputusan yang telah direncanakan.

Salah satu fungsi darimediamassaadalah sebagai sarana informasi. Media social yang merupakan dari media baru, yang merupakan perkembangan dari media massa juga memiliki peranan sebagai sarana informasi. Media baru merupakan sebuah pengembangan dari media dan teknologi yang memudahkan khalayak dalam memberikan dan mendapatkan informasi. Kemunculan media baru diharapkan dapat memberikan peningkatan produktifitas dan kesempatan belajar dan kreatifitas terkini yang terbuka dan sifat komunikasi yang horizontal atau merata (Lister,2009:11).

Kemudian menurut Siapera (2012:202), gaya komunikasi di dalam social media berdasarkan karakteristik media sosial antara lain adalah: 1) Communicative 2) Open and Participatory. 3) Provide connectivity, 4) Support community , 5) Actively encourage and rely upon the creation and sharing of contents. Informasi yang disampaikan kepada para penggunanya tidak lagi berbentuk satu arah, melainkan dua arah di mana para pengguna nya dapat membagi informasi dan konten yang mereka anggap penting, informatif maupun unik untuk dibagikan.

Gaya komunikasi yang digunakan di media sosial Instagram @ibunda_id akan menjadi variabel independen dalam penelitian ini dengan indikator berdasarkan gaya komunikasi di dalam social media menurut karakteristik media social, yaitu: communicative, open and participatory, provide connectivity, support community, dan actively encourage and rely upon the creation and sharing of contents. Kemudian, bagaimana platform konsultasi online Ibunda menggunakan gaya komunikasi dalam memberikan informasi dan mempengaruhi tingkat brand awareness terhadap Ibunda.

Menurut Durianto, Sugiarto dan Sitinjak, (2004: 4), brand awareness adalah kesanggupan seorang calon pembeli untuk mengenali, mengingat kembali suatu merek sebagai bagian dari suatu kategori produk tertentu. Brand awareness terdiri atas hasil brand recognition dan brand recall. Brand recognition adalah kemampuan konsumen untuk mengkonfirmasi eksposur sebelumnya kepada brand ketika brand diberikan bantuan. Brand recall adalah kemampuan konsumen untuk mengingat brand dari memori ketika diberikan kategori produk (Kotler dan Keller,2008: 77).

Tingkat Brand Awareness menurut Durianto, et.al (2004: 6) antara lain adalah: 1) Top of Mind (puncak pikiran) merupakan merek yang disebutkan pertama kali oleh konsumen atau yang pertama kali muncul dalam benak konsumen. 2) Brand Recall (pengingatan kembali), merek mencerminkan merek-merek apa yang diingat responden setelah menyebutkan merek yang pertama kali disebut. Brand Recall merupakan multiresponse question. 3) Brand Recognition (pengenalan merek), merupakan pengukuran brand awareness dimana kesadarannya diukur setelah responden diberikan bantuan yang dapat mengenal brand tersebut.

Kemudian, paradigma penelitian menurut Lincoln dan Guba (2005:107) yang digunakan dalam penelitian ini adalah klasik. Paradigma klasik dikenal sebagai sebagai metode yang teroganisir, bertujuan untuk memperoleh konfirmasi hukum sebab akibat yang hasilnya nanti dapat digunakan untuk memprediksi pola-pola umum 
mengenai gejala social tertentu. Oleh karena itu, dengan adanya tujuan penelitian ini yaitu untuk mengetahui pengaruh konten dan gaya komunikasi dalam media sosial platform konsultasi online @ ibunda_id terhadap brand awareness@ibunda_id secara simultan.

Tipe penelitian yang digunakan dalam penelitian ini adalah eksplanatif kausalitas dengan pendekatan kuantitatif. Metode ekspalanatif digunakan untuk menjelaskan hubungan kausal antara variabelvariabel melalui pengujian hipotesis. Penelitian eksplanatif dilakukan terhadap sampel dan hasil penelitian tersebut dapat digeneralisasikan terhadap populasinya (Bungin, 2007: 124). Tujuan dari metode kuantitatif eksplanatif adalah untuk menjelaskan secara umum mengenai pengaruh konten dan gaya komunikasi dalam media social platform konsultasi online@ibunda_id terhadap brand awareness@ibunda_id.

Teknik analisis data yang digunakan dalam penelitian ini adalah deskriptif di mana data akan disajikan dalam table frekuensi sederhana dan menggunakan statistik deskriptif (Kriyantono, 2006: 68).

Populasi diambil dari jumlah followers akun Instagram@ibunda_id yang terdiri dari 3,857 orang pada tanggal 8 Maret 2017 dan menggunakan teknik sampel purposive sebanyak 100 sampel atau 10\% dari populasi (Nugroho, 2005: 146-147). Dengan kriteria: 1) Followers akun Instagram @ Ibunda_id; 2) Laki-laki dan perempuan, dan 3) Tertarik dengan platform konsultasi online Ibunda.

Data primer dikumpulkan melalui penyebaran kuesioner dengan menggunakan skala pengukuran yaitu skala Likert. Teknik analisis data yang digunakan dalam penelitian ini adalah statistik deskriptif untuk memberikan gambaran secara detail mengenai Konten, Gaya Komunikasi dan Brand Awarenes. Sebanyak 30 butir pernyataan disebarkan menggunakan kuesioner kepada 100 sampel yang telah ditentukan.

Selanjutnya akan dilakukan analisis regresi linier berganda untuk mengetahui pengaruh antara Konten dan Gaya Komunikasi secara simultan terhadap Brand Awareness. Dilakukan pre test uji validitas dan reliabitas kepada 30 responden yang hasilnya menyatakan bahwa semua pertanyaan dinyatakan valid dan reliabel yang kemudian dilakukan test secara keseluruhan terhadap 100 responden.

Hipotesis Penelitian

Ha1 : Terdapat pengaruh antara konten di media sosial Instagram @Ibunda_id terhadap brand awareness.

Ho1: Tidak ada pengaruh antara konten di media sosial Instagram @ibunda terhadap brand awareness.

Ha2: Terdapat pengaruh mengenai gaya komunikasi di media sosial Instagram @ Ibunda_id terhadap brand awareness.

Ho2: Tidak ada pengaruh mengenai gaya komunikasi di media sosial Instagram @ Ibunda_id terhadap brand awareness.

Ha3 : Terdapat pengaruh mengenai konten dan gaya komunikasi di media sosial Instagram @Ibunda_id secara simultan terhadap brand awareness.

Ho3: Tidak ada pengaruh mengenai konten dan gaya komunikasi di media sosial Instagram @Ibunda_id secara simultan terhadap brand awareness.

\section{TEMUAN DAN DISKUSI}

Karakteristik responden berdasarkan usia menyatakan bahwa pengguna layanan Ibunda.id didominasi oleh responden yang berusia $21-30$ tahun sebanyak 89 orang (89\%). Disusul sebanyak 10 orang $(10 \%)$ berusia dibawah 20 tahun. Hal ini menyatakan pengguna layanan@Ibunda_id merupakan usia muda produktif sehingga pada usia tersebut pengguna cenderung masih mencoba untuk melakukan banyak hal. Sedangkan, responden yang menggunakan layanan Ibunda.id berusia $31-40$ tahun hanya berjumlah 1 orang $(1 \%)$.

Karakteristik responden berdasarkan pekerjaan menyatakan bahwa pengguna layanan Ibunda. id terbesar berprofesi sebagai mahasiswa yaitu sejumlah 47 orang (47\%). Setelah itu disusul 41 orang (41\%) berprofesi sebagai pegawai dan 10 orang $(10 \%)$ merupakan pelajar.

Karakteristik responden berdasarkan intensitas penggunaan layanan Ibunda.id dalam 3 bulan 
terakhir diketahui bahwa intensitas responden menggunakan layanan @Ibunda_id terbanyak adalah 1 kali semingu dengan presentase 93 orang (93\%) dan kemudian diikuti sebanyak 7 orang (7\%) menggunakan layanan Ibunda.id dengan intensitas 2-5 kali dalam seminggu. Hal tersebut dapat diartikan bahwa responden masih menjadikan layanan konsultasi@Ibunda id sebagai pilihan alternatif bagi mereka dalam melakukan konsultasi dan mencari solusi terhadap masalah yang sedang dihadapi.

Tabel 1. Uji Koefisien Determinasi

\begin{tabular}{llrrr}
\hline & & & & \\
Model & R & R Square & $\begin{array}{c}\text { Adjusted R } \\
\text { Square }\end{array}$ & $\begin{array}{c}\text { Std. Error of the } \\
\text { Estimate }\end{array}$ \\
1 & $.708^{\mathrm{a}}$ &, 502 &, 492 &, 25697 \\
\hline
\end{tabular}

a. Predictors: (Constant), Dimensi 2, Dimensi 1

b. Dependent Variable: Dimensi 3

Sumber : Data Olahan Peneliti, 2017

Hasil penelitian menyatakan bahwa kontribusi konten dan gaya komunikasi di @ibunda_id dalam menjelaskan brand awareness adalah sebesar $49,2 \%$ dan sisanya $51 \%$ dijelaskan oleh faktor- faktor lain seperti kredibilitas komukator, brand image dan terpaan media sosial (frekuensi dan durasi penggunaan)@Ibunda_id

Tabel 2. Uji t

\begin{tabular}{|c|c|c|c|c|c|c|c|}
\hline \multirow{3}{*}{$\begin{array}{l}\text { Model } \\
\text { (Constant) }\end{array}$} & \multicolumn{2}{|c|}{$\begin{array}{l}\text { Unstandardized } \\
\text { Coefficients }\end{array}$} & \multirow{2}{*}{$\begin{array}{c}\text { Standardized } \\
\text { Coefficients } \\
\text { Beta }\end{array}$} & \multirow[b]{2}{*}{$\mathbf{t}$} & \multirow[b]{2}{*}{ Sig. } & \multicolumn{2}{|c|}{$\begin{array}{l}\text { Collinearity } \\
\text { Statistics }\end{array}$} \\
\hline & B & $\begin{array}{l}\text { Std. } \\
\text { Error }\end{array}$ & & & & Tolerance & VIF \\
\hline & 1,131 & ,269 & & 4,207 & ,000 & & \\
\hline $\begin{array}{l}\text { Variabel } \\
\text { X1 }\end{array}$ &, 145 &, 075 &, 173 & 1,935 & ,006 & ,639 & 1,566 \\
\hline $\begin{array}{l}\text { Variabel } \\
\mathrm{X} 2\end{array}$ &, 530 &, 081 & ,590 & 6,584 &, 000 & ,639 & 1,566 \\
\hline
\end{tabular}

Ha1: Terdapat pengaruh antara konten di media sosial Instagram@Ibunda_id terhadap brand awareness.

Variabel konten mempunyai t hitung lebih besar dari t tabel $(1,935>1,066)$. Hal ini menunjukan bahwa Ho ditolak dan Ha diterima yang artinya terdapat pengaruh antara variabel konten terhadap brand awareness. Nilai koefisien regresi (b) sebesar 0,145 menunjukan bahwa terdapat pengaruh yang positif dimana setiap peningkatan konten di media sosial Instagram sebesar 1 unit akan meningkatkan brand awareness sebesar 0,145 unit. Kemudian, pada hasil perhitungan rata-rata per variable, diperoleh rata-rata untuk variable konten yaitu 3,8 yang termasuk dalam kategori tinggi karena nilai rata-rata keseluruhan kategori tinggi berkisar antara 3,41 sampai dengan 4,20.

Hal tersebut juga diutarakan dalam teori Social Information Processing yang memandang fenomena pengembangan hubungan dalam format Computer Mediated Communication di mana para komunikator bertemu melalui komunikasi berbasis teks komputer dan mengembangkan kesan dan hubungan interpersonal. Dalam penelitian ini, 
menghasilkan bahwa @Ibunda_id berhasil membangun komunikasi di media sosial Instagram melalui konten-konten yang diberikan secara rutin, relevan dan mudah dimengerti.

Ha2: Terdapat pengaruh mengenai gaya komunikasidi media sosial Instagram @Ibunda_id terhadap brand awareness.

Variabel gaya komunikasi mempunya t hitung lebih besar dari t tabel $(6,584>1,066)$. Hal ini menunjukan bahwa Ho ditolak dan Ha diterima yang artinya terdapat pengaruh antara variabel gaya komunikasi terhadap brand awareness. Nilai koefisien regresi (b) sebesar 0,530 menunjukan bahwa terdapat pengaruh yang positif dimana setiap peningkatan gaya komunikasi di media sosial Instagram sebesar 1 unit akan meningkatkan brand awareness sebesar 0,530 unit. Lalu, diperoleh juga rata-rata untuk variable gaya komunikasi yakni sebesar 3,9 yang termasuk dalam kategori tinggi. Gaya komunikasi yang komunikatif dan terbuka didominasi dengan sikap setuju karena dalam berkomunikasi, Ibunda kerap memberikan dorongan, motivasi serta solusi cara untuk menghadapi dan menyelesaikan masalahmasalah yang sedang dihadapi.

Gaya komunikasi di media Instagram yang bertipe verbal dan nonverbal berupa caption, mention dan foto membuktikan bahwa gaya komunikasi sangat penting dan bermanfaat karena akan memperlancar proses komunikasi dan menciptakan hubungan yang harmonis. Gaya komunikasi yang terbuka juga dilakukan oleh Ibunda. Hal tersebut dilakukan dengan tujuan agar para pengikut Ibunda.id dapat membagi pengalaman atau pendapat mereka mengenai konten atau permasalahan yang sedang terjadi.

Tabel 3. Uji F

\begin{tabular}{lrrrrrr}
\hline & \multicolumn{1}{c}{$\begin{array}{c}\text { Sum of } \\
\text { Model }\end{array}$} & \multicolumn{1}{c}{ Squares } & Df & \multicolumn{1}{c}{$\begin{array}{c}\text { Mean } \\
\text { Square }\end{array}$} & F & \multicolumn{1}{c}{ Sig. } \\
Regression & 6,453 & & 2 & 3,227 & 48,863 & $.000^{\mathrm{b}}$ \\
Residual & 6,405 & 97 &, 066 & & \\
Total & 12,858 & 99 & & & \\
\hline
\end{tabular}

Sumber: Data Olahan Peneliti, 2017

Ha3 : Terdapat pengaruh antara konten dan gaya komunikasi di media sosial Instagram @ibunda secara simultan terhadap brand awareness.

Diperoleh hasil bahwa $\mathrm{F}_{\text {hitung }}$ sebesar 48,863 sedangkan nilah $\mathrm{F}_{\text {tabel }} F_{\text {tabel }}$ sebesar 3,09, Hal tersebut menunjukan bahwa $\mathrm{F}_{\text {hitung }}>\mathrm{F}_{\text {tabel }}=48,863$ $>$ 3,09 yang berarti bahwa $\mathrm{H}_{0}$ ditolak dan $\mathrm{H}_{\mathrm{a}}$ diterima, maka terdapat pengaruh mengenai konten dan gaya komunikasi di social media Instagram @ ibunda secara simultan terhadap brand awareness.

Hasil penelitian juga menyatakan bahwa gaya komunikasi merupakan factor yang dominan mempengaruhi brand awareness. Artinya, penggunaan gaya komunikasi yang komunikatif, terbuka, menunjukan empati pada followers yang sedang mengalami persoalan, memberikan dukungan dan umpan balik berupa opsi dalam menyelesaikan masalah merupakan gaya komunikasi yang disukai oleh follower@Ibunda id. Gaya berkomunikasi terkadang menjadi lebih penting dari konten komunikasi tersebut. Bagaimana tidak, banyak orang yang memahami konten dengan baik tetapi pesan komunikasinya tidak sampai atau tidak diterima orang lain karena ketidakmampuan dalam menyampaikan pesan tersebut.

Selain dukungan, dorongan, rasa empati dan perhatian yang harus diberikan kepada kerabat atau orang terdekat yang sedang menghadapi permasalahan, solusi juga menjadi salah satu hal yang sangat dibutuhkan oleh khalayak ketika sedang menghadapi permasalahan sehari-hari. Hal 
itu pula yang dilakukan oleh@Ibunda_id melalui beberapa bentuk posting di akun Instagram (gambar 1). Lalu, berdasarkan hasil data deskriptif sebanyak 79 orang $(79 \%)$ merasa mendapatkan dukungan oleh Ibunda dalam menghadapi masalah.

Pemberian dukungan, dorongan, rasa empati dan perhatian selain diberikan dalam setiap konten di akun Instagram Ibunda, juga diberikan melalui adanya support group setiap bulannya. Support group tersebut bertujuan untuk membeikan wadah kepada para peserta untuk melepas beban pribadi ke dalam sebuah forum yang dalam forum tersebut akan difasilitasi oleh moderator dibidang psikologi. Solusi yang diberikan berupa video yang menampilkan para pakar atau konten dengan visual dan teks yang menarik untuk dibaca.

Gaya komunikasi yang komunikatif dicerminkan melalui setiap konten yang telah di posting pada@Ibunda_id. Selain itu, Ibunda pun memberikan informasi tidak hanya berupa teks tetapi dipadukan pula dengan visual yang menarik sehingga pengguna nya tidak jenuh ketika membaca informasi tersebut.

Bentuk gaya komunikasi yang terbuka menjadi salah satu aspek yang menjadikan Ibunda diminati oleh penggunanya. Ibunda selalu terbuka dalam menerima konsultasi. Kemudahan dalam melakukan konsultasi diwujudkan melalui opsi dalam memilih penggunaan media apa dalam melakukan konsultasi. Konsultasi dapat dilakukan melalui berbagai media seperti social media, Line@Account atau live chat di dalam website Ibunda. Hal tersebut didukung oleh hasil data yang menyatakan bahwa sebanyak 84 orang (84\%) setuju bahwa Ibunda secara terbuka menerima konsultasi. Lalu, Ibunda kerap mengajak para pengikutnya untuk berpatisipasi memberikan feedback di setiap konten yang di posting. Hal tersebut disetujui sebanyak 77 orang $(77 \%)$ dari jumlah keseluruhan responden.

Konten berupa informasi mengenai permasalah sehari-hari seputar permasalahan diri, pertemanan dan keluarga yang disampaikan oleh@Ibunda id aktual karena secara konsisten Ibunda memposting konten informasi pada akun Instagramnya 1-2 hari sekali bahkan terkadang dalam 1 hari @Ibunda_id mem-posting konten informasi sebanyak 2 kali. Hal tersebut menunjukan bahwa@Ibunda_id menginginkan pengikut Instagramnya mendapatkan informasi sesering dan sebanyak mungkin. Ibunda juga berusaha untuk terus mengikuti fenomena yang sedang terjadi. Hal tersebut dapat dilihat melalui hasil data yakni mayoritas orang $(95 \%)$ menyatakan setuju bahwa informasi mengenai permasalahan seharihari seputar percintaan, pertemanan, keluarga dan masalah diri yang diberikan di akun Instagram Ibunda merupakan permasalahan yang sedang menjadi pembicaraan banyak orang.

Konten yang diberikan pun beragam, mulai dari segmen bernama "Kata Bunda" yakni informasi seputar permasalahan sehari-hari berupa penjelasan masalah yang sangat dekat dengan kehidupan sehari-hari dan informasi mengenai solusi yang juga di hubungkan ke artikel yang terdapat di website Ibunda. Lalu, segmen "Ibunda's Fact" yaitu informasi mengenai fakta-fakta seputar masalah psikologi yang dialami dalam kehidupan sehari-hari. Selain itu, informasi diberikan juga berupa video yang melibatkan sejumlah pakar psikolog untuk membahas berbagai masalah tentang percintaan, pertemanan, keluarga dan masalah diri.

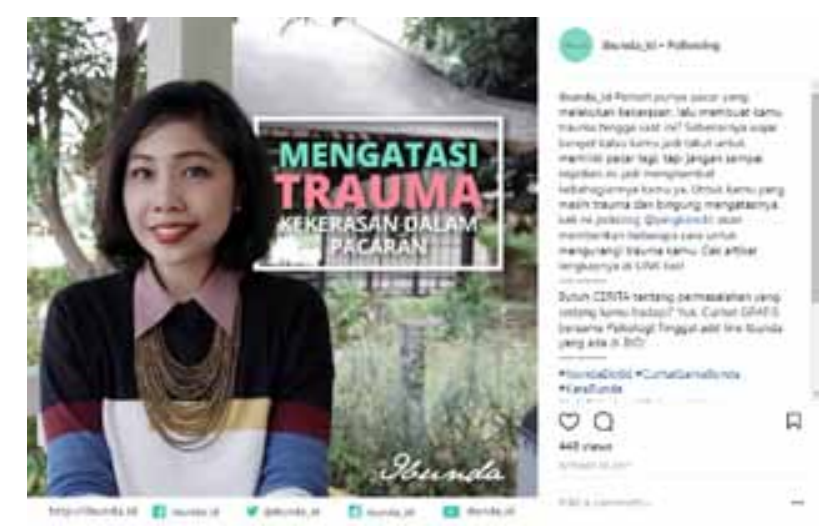

Gambar 1. Konten Video Ibunda

Sumber: Instagram @Ibunda_id, 2017

Selain itu, berdasarkan analisis deskriptif diketahui sebanyak 73 orang (73\%) menyatakan setuju bahwa topik atau informasi yang diberikan oleh Ibunda sesuai dan relevan dengan persoalan yang sedang dihadapi. Contoh konten yang dianggap relevan oleh para pengikutnya adalah dengan adanya sejumlah komentar yang diberikan followers Instagram @Ibunda_id. Pada posting- 
an yang menanyakan "Kalau punya orang yang sayang kamu, kenapa harus menyimpan semua masalah sendiri?" Hal ini sesuai dengan layanan @Ibunda_id yang menjadi ajang curhat bagi para follower-nya.

Bagaimana mengenai brand awareness @ Ibunda_id. Keberadaan@Ibunda.id sebagai platform konsultasi online merupakan sebuah hal yang cukup baru mengingat @Ibunda.id telah memiliki asosiasi dengan lembaga dan komunitas dibidang psikologi. Berdasarkan analisis deskriptif diketahui bahwa 72 orang $(72 \%)$ menyatakan setuju bahwa mereka mengingat @ibunda_id sebagai platform konsultasi berbasis online.

Para pengguna Instagram @Ibunda id mengingat Ibunda sebagai paltform konsultasi berbasis online disebabkan karena Ibunda secara rutin memberikan informasi yang relevan dengan permasalahan kehidupan sehari-hari. Hal ini selaras dengan temuan penelitian yang menyatakan bahwa mayoritas responden sejumlah 46 orang (46\%) menyatakan setuju bahwa ketika mereka sedang dihadapi permasalahan sehari-hari, mereka akan membuka akun Instagram @ibunda_id untuk mencari konten yang relevan dengan masalah yang sedang dihadapi untuk mencari referensi dalam menyelesaikan masalah atau hanya sekedar untuk mendapatkan dorongan dari pengguna yang memiliki permasalahan yang sama.

Sebagai platform konsultasi online berbasis psikologi, Ibunda.id berharap bahwa paltform nya dapat memberikan manfaat kepada para pengguna nya. Dalam penelitian ini yang berfokus pada konten dan gaya komunikasi Ibunda.id yang diberikan di akun Instagram@ibunda id, sebanyak 80 (80\%) orang menyatakan setuju bahwa akun Ibunda di Instagram memberikan manfaat dibanding platform konsultasi lainnya melalui konten-konten dan gaya komunikasi yang digunakan oleh Ibunda pada akun media sosial dan website Ibunda.

Temuan penelitian mengenai @Ibunda id sebagai pilihan pertama sebagai platform konsultasi berbasis online adalah sejumlah 56 orang dengan presentase sebesar $56 \%$ menyatakan setuju yang berarti responden memilih @ibunda id sebagai pilihan pertama Salah satu keunggulan dari@Ibunda_id adalah platform konsultasi online yang terbilang mudah digunakan dan tidak dipungut biaya atau gratis bagi mereka yang ingin melakukan curhat. Berbeda dengan platform lain yang sejenis yang mematok harga sesuai dengan pilihan paket yang dibutuhkan oleh penggunanya ketika mereka ingin berkonsultasi.

Selanjutnya, apakah @ibunda_id identik dengan platform konsultasi berbasis online yang memberikan solusi yang tepat? Hal ini dapat dilihat bahwa sebanyak 70 orang (70\%) menyatakan setuju bahwa solusi yang diberikan oleh@Ibunda id dapat diimplementasikan ke dalam penyelesaian masalah sehari-hari yang sedang dihadapi. Hal tersebut dapat dilihat pada konten yang diunggah oleh@Ibunda_id yang berjudul "Tak Perlu Malu Sebagai Anak Broken Home" pada 22 November 2017. @Ibunda_id memberikan pandangannya terhadap permasalahan tersebut dan memberikan dukungan serta solusi mengenai cara menyikapi keluarga broken home. Dari konten tersebut, terdapat komentardarifollowers@Ibunda_id yang menyatakan setuju dengan solusi yang diberikan oleh Ibunda dalam menyikapi keluarga broken home.

Kembali kepada Teori Social Information Processing yang diterapkan pada media sosial Instagram maka tidak terpaku pada aspek teknis media perantara, namun juga mempertimbangkan kemampuan manusia sebagai komunikan untuk beradaptasi. Pada penelitian ini, keberhasilan@ Ibunda_id tidak hanya berdasarkan konten dan gaya komunikasi dari@Ibunda_id namun juga bergantung pada tim psikolog yang menjadi salah satu komunikan di@Ibunda_id. Tim psikolog yang dimiliki oleh Ibunda merupakan para pakar psikologi yang memiliki kredibilitas dibidangnya.

Asumsi yang digunakan adalah isu komunikasi relasional tidak terletak pada kemampuan, melainkan pada taraf penyampaian media perantara (Walther,1996: 53). Dengan kata lain, jika komunikan diberikan waktu yang cukup, maka interaksi yang terjadi melalui media sosial pada akhirnya akan mampu mencapai tingkat yang sama atau sebanding dengan interaksi tatap muka. Artinya dampak keterikatan akan berbeda sejalan dengan frekuensi dan durasi dari para pengguna @ Ibunda_id mengakses dan berkomunikasi dengan 
tim psikolog melalui@Ibunda_id.

Kaitannya dengan penelitian adalah berbagai posting@Ibunda_id berupa bentuk dukungan @Ibunda_id terhadap penggunanya. Contoh@ Ibunda_id memberikan komentar "Lebih Baik Melangkah Tersesat Daripada Diam Di tempat." Atau "Jatuh Cintah Boleh Tapi Jangan Lupakan Logika Ya." Bentuk posting berupa dukungan tersebut banyak mendapat respon like dan komentar dari para followers. Kemudian, pesan yang disampaikan oleh Ibunda selalu berusaha untuk netral tanpa menyudutkan satu pihak tertentu dan menampilkan citra positif.

\section{SIMPULAN}

Berdasarkan hasil penelitian, maka terdapat pengaruh yang positif dan signifikan antara konten dan gaya komunikasi di media sosial Instagram @ibunda_id terhadap brand awareness. Setiap peningkatan konten di dan gaya komunikasi akan meningkatkan brand awareness@Ibunda_id

Pengaruh paling dominan terhadap brand awareness@Ibunda_id adalah gaya komunikasi. Artinya, penggunaan gaya komunikasi yang komunikatif, terbuka dalam menerima feedback dan konsultasi dari para penggunanya. Hal tersebut didukung dengan pernyataan Sholikhah (2014:46) bahwa dalam hal ini gaya komunikasi menjadi penting untuk diterapkan. Gaya berkomunikasi terkadang menjadi lebih penting dari konten komunikasi tersebut. Bagaimana tidak, banyak orang yang memahami konten dengan baik tetapi pesan komunikasinya tidak sampai atau tidak diterima orang lain karena ketidakmampuan dalam menyampaikan pesan tersebut.

Selain itu, dapat dikaji lebih dalam apakah terdapat interaksi offline antara followers @ Ibunda_id dengan tim psikolog setelah para followers tersebut merasa nyaman untuk melakukan curhat di@Ibunda id. Apakah dibuka kemungkinan followers dapat menghubungi tim psikolog untuk bertemu offline? Hubungan yang awalnya bersifat online apakah berlanjut menjadi interaksi offline? Hal ini menarik untuk dikaji, dan membuat perbandingan antara kualitas interaksi offline dan online.

\section{DAFTAR PUSTAKA}

Arjanti, Raden dan Mosal, Renedy. 2012. Startup Indonesia. Buku Kompas

Bungin, Burhan. 2007. Penelitian Kualitatif. Jakarta: Kencana. Edisi pertama, cetakan ketiga.

Creeber, Glen., dan Martin, Royston. 2009. Digital Cultures. New York: Open University

Durianto, Darmadi., Sugiarto, dan Sitinjak, Tony. 2004. Strategi Menaklukkan Pasar Melalui Riset Ekuitas dan Perilaku Merek. Jakarta: PT. Gramedia Pustaka Utama.

Kaplan, Andreas., dan Haenlein, Michael. 2010. Users of the world, unite! The challenges and opportunities of Social Media. Business Horizons.

Kotler, Philip,.dan Keller, Kevin. 2008. Manajemen Pemasaran. Penerbit Erlangga. Jakarta.

Kriyantono, Rachmat. 2006. Teknik Praktis Riset Komunikasi. Jakarta: PT. KencanaPrenada Media Group.

Lincoln, Yvonne., dan Guba, Egon.2005. The Sage Handbook of Qualitative Research (3 ${ }^{\text {rd }}$ Edition). Thounsand Oaks, CA: Sage.

Lister, Martin. 2009. New Media: a critical introduction.

Newyork: Routledge

Littlejohn, Stephen., dan Foss, Karen. 2009. Teori Komunikasi. Jakarta: Salemba

Nugroho, Agung. 2005. Strategi Jitu Memilih Metode Statistik Penelitian dengan SPS. Andi Yogyakarta.

Severin, Werner., dan Tankard, James. 2005. Teori Komunikasi: Sejarah, Metode, \& Terapan di Dalam Media Massa, Edisi Ke5. Jakarta: Kencana

Siapera.2012. Understanding New Media. Sage Publication.

Walther, Joseph. 2010. ComputerMediated Communication Impersonal, Interpersonal, and Hyperpersonal Interaction. Journals of Sage, Vol. 23, No. 1 (pages 3-43).

Widjaja, Tunggal. 2000. Auditing Suatu Pengantar. Jakarta: Penerbit Rineka Cipta.

Wiryanto. 2004. Pengantar Ilmu Komunikasi. Jakarta: Grasindo 